\title{
Determinants of the round-to-round returns to pre-IPO venture capital investments in U.S. biotechnology companies
}

\author{
John R. M. Hand \\ Kenan-Flagler Business School \\ UNC Chapel Hill \\ Chapel Hill, NC 27599-3490
}

\author{
Tel: (919) 962-3173 \\ Fax: (919) 962-4727 \\ hand@unc.edu
}

\begin{abstract}
I propose that pre-IPO venture-backed biotech companies offer a useful new setting through which to evaluate the relative merits of theories for why firm size and book-to-market explain variation in stock returns. This is because pre-IPO biotech firms have large and rapidly evolving growth options relative to assets-in-place. Such attributes align closely with the key features of Berk et al.'s (1999) model of the endogenous relations between growth options, optimal investment actions and expected equity returns, where firm size and book-to-market emerge as sufficient statistics for the aggregate risk of a firm's assets-in-place. Using venture capital investments in pre-IPO U.S. biotech companies during 1992-2001, I find that equity returns between financing rounds ('round-to-round' returns) are reliably negatively related to firm size and positively related to book-to-market ratios. I interpret these results as being most consistent with Berk et al.'s theory, and less consistent with alternative explanations such as financial distress, behaviorally biased investors or data snooping.
\end{abstract}

Key words: $\quad$ Book-to-market; firm size; growth options; risk; round-to-round returns.

First draft: October 15, 2003

This version: September 19, 2005

Forthcoming, Journal of Business Venturing

I am grateful to two anonymous referees, and to J. Abarbanell, J. Conrad, W. Ferson, P. Fulghieri, C. Harvey, J. Hughes, P. Jorion, S.P. Kothari, J. Lerner, L. Lindsey, J. Liu, A. Shivdasani, M. Williams, H. Zhang and seminar participants at UCLA, UNC and the 2004 Conference on Financial Economics \& Accounting at USC for their valuable comments. My thanks also to M. Mumma and G. Kong of InterSouth Partners and F. Worthy of A. M. Pappas \& Associates for sharing their insights into venture capital valuation, and M. Edwards, J. Lerner, S. Woodward and VentureOne for generously sharing their data. The Edward O'Herron, Jr. Fund for Distinguished UNC Faculty, the UNC Center for Entrepreneurship, and the UNC Center for Technology \& Advanced Commerce provided financial support. All errors are my own. 


\section{Executive summary}

Venture investors supply equity capital to start-up technology firms to finance the conversion of those firms' new ideas into tangible products and services. This paper evaluates whether the returns earned by venture investors reflect the pricing of similar types of risks as in publicly traded stocks, and why. In particular, I focus on the pricing of firm size and book-to-market.

Pre-IPO venture-backed firms offer a powerful setting for doing this because they have few hard assets but large amounts of growth options. These characteristics underpin new approaches to analyzing risk and return based on Berk et al. (1999). Berk et al. theorize that firm size and book-to-market are priced in equity returns because they reflect firms' optimal exercising of their growth options, and the changing relative importance of hard assets and growth options.

Venture-backed firms and venture investors also tend not to have the characteristics called for by competing explanations for why firm size and book-to-market are priced in equity returns. For example, venture capital data is largely free of 'research snooping' biases. Although venture investors on average earn high returns, the typical book-to-market ratio of a venture-backed firm is very low, not high. And because the general partners in venture capital funds are sophisticated businesspeople, explanations that rely on naïve investors would seem less likely to apply.

I assess the pricing of firm size and book-to-market in venture returns using U.S. biotech firms during 1992-2001. Biotech firms are numerous and have large technology-oriented growth opportunities. Book-to-market ratios can be computed because when firms file to go public they report up to five years of prior financial statements. I combine this financial statement data with non-financial statement data (e.g., on patents filings and strategic alliances) and the firm-specific returns that venture investors earn between financing rounds.

Using regression analysis, I find that venture capitalists' 'round-to-round' returns are reliably larger the smaller is the size of the firm they invest in and the larger is its book-to-market ratio. Overall, my results suggest that venture capitalists are rewarded for some of the same key economic risks as public market investors when supplying capital to pre-IPO technology companies, and for reasons that most likely reflect firms' dynamically optimal investment decisions concerning both their hard assets and their growth options. 


\section{Introduction}

There is wide agreement that firm size and book-to-market help explain the expected returns to publicly traded stocks. There is far less agreement on why. In this paper, I present a new setting in which alternative theories for the firm size and book-to-market phenomena can be tested. The setting is the 'round-to-round' returns earned by venture capital investments in preIPO U.S. biotech companies. It is an appealing and informative setting for two reasons.

First, pre-IPO biotech firms have very large and rapidly evolving growth options relative to assets-in-place. These characteristics align closely with the key features of Berk et al.'s (1999) recent theory of the endogenous relations between firms' growth options, optimal investment actions and expected equity returns. In Berk et al.'s model, firm size and book-to-market emerge as sufficient statistics for the aggregate risk of firms' assets-in-place. Firm size is negatively related to expected returns because it is a proxy for the state variable that describes the importance of assets-in-place relative to growth options. Book-to-market is positively related to expected returns because is a proxy for the state variable that summarizes firm risk relative to the scale of firm assets-in-place. I find these predicted relations are indeed present in my sample.

Second, venture-backed firms and venture investors also tend not to have the characteristics called for by competing explanations for why firm size and book-to-market are priced in equity returns. For example, Fama and French (1993) propose that small firms and high book-to-market firms earn high returns because firm size and book-to-market are proxies for financial distress risk. Their hypothesis predicts that pre-IPO biotech firms that are small and/or have high bookto-market ratios will earn high returns. However, although pre-IPO biotech firms are indeed small and on average earn high returns between successive financing rounds (henceforth, 'roundto-round' returns) they also have very low, not high, book-to-market ratios.

Pre-IPO biotech firms are also primarily financed by venture capital funds whose general partners are sophisticated and experienced businesspeople. As a result, Lakonishok et al.'s (1994) hypothesis that high book-to-market stocks earn high returns because investors are naïve - they incorrectly extrapolate past poor earnings growth - predicts that there will be no relation between returns and book-to-market ratios for pre-IPO venture-backed biotech firms.

Lastly, Lo and MacKinlay (1990) and Black (1993) suggest that repeated analysis on the same publicly traded stock return data means that anomalous findings such as the pricing of firm size and book-to-market merely reflect in-sample data mining and/or misplaced reliance on classical statistics. However, the prior literature on the relations between firm size, book-tomarket and returns in the pre-IPO market consists of one study of one fund's private equity portfolio (Gompers and Lerner, 1998). Thus the data snooping explanation for why firm size and book-to-market help explain variation in expected returns does not predict there will be a relation between firm size, book-to-market and expected returns for pre-IPO biotech firms.

Although the setting of venture capital investments in pre-IPO biotech firms offers a novel opportunity for testing firm size and book-to-market theories, it comes with a potentially significant threat to inferential validity. The threat arises because the financial statement data needed to construct firms' book-to-market ratios are only available for the subset of all venture- 
backed biotech firms that have on average experienced the largest round-to-round returns, namely those that filed to go public. (Private firms are not required to publicly disclose financial statement data unless and until they file for an IPO, at which time they must report summary balance sheet and income statement information for the past five years). This selection bias raises the concern that the associations between returns, firm size and book-to-market observed in my pre-IPO dataset are spurious and not a true reflection of the economic forces modeled by Berk et al. I investigate in some detail the relevance of selection bias using both Heckman and non-Heckman approaches and conclude that selection bias is likely not a major inferential threat.

Overall, I conclude that cross-sectional variation in the round-to-round returns earned by venture capital investments in pre-IPO biotech companies is probably best explained by Berk et al.'s reasoning for the relations between firm size, book-to-market and expected returns. The predictions made by competing explanations such as financial distress, investor irrationality and data snooping receive weaker empirical support.

The rest of the paper proceeds as follows. Section 3 briefly describes the venture capital market and the economic distinctives of venture-backed biotech firms. Section 4 summarizes the existing literature on the risks and returns to venture capital, and develops the predictions that competing theories of the pricing of firm size and book-to-market make for pre-IPO biotech companies. Section 5 develops a model of the determinants of round-to-round returns. Section 6 details the variables used in the empirical analysis. Section 7 provides descriptive statistics. Section 8 reports the results of estimating the model of returns and a variety of supplementary tests aimed at assessing the impacts of selection bias. Section 9 summarizes and concludes.

\section{The economic distinctives of venture-backed biotechnology companies}

\subsection{Venture capital and the economic distinctives of venture-backed firms}

Venture capital is the subpart of organized private equity that invests in young, typically high technology firms. The typical investment made by a venture fund in a company is in the form of illiquid preferred stock that only converts into liquid common stock or cash at one of two major exit points - an IPO, or the sale of the company to another entity.

Venture-backed firms are predominantly technology- or innovation-driven companies that are in the most formative years of their life. They derive far less of their equity value from assets-inplace than do more mature, publicly traded firms. Instead, the lion's share of their equity value stems from the intangible-intensive growth options that dominate their investment opportunity sets. Because the dominant role of intangibles in technology- and innovation-driven young companies creates large agency costs and information asymmetries between them and potential suppliers of capital (Gompers and Lerner, 2000a), a key contribution that venture capitalists make is in designing and implementing solutions to these agency problems, such as staging their financing and encouraging firms to use substantial amounts of equity-based compensation. Venture-backed firms are also very dynamic in the sense that they grow more rapidly and flexibly than do their public market counterparts (Hellman, 2000). They tend to uncover new investment opportunities faster, develop them quicker and more professionally, and are more ready to discard and abandon bad projects than more seasoned companies (Hellman and Puri, 
2000; 2002). In all, venture-backed firms have rapidly evolving investment opportunity sets that are dominated by very risky_-but potentially also very profitable — growth options.

\subsection{Biotechnology and biotechnology firms}

Biotechnology is the application of technology to the life sciences wherein living cells or their processes are used to solve problems and to perform specific industrial or manufacturing processes. The typical biotech value chain is long and uncertain, stretching some 10-15 years from founding through patenting to successful FDA approval and product sales.

Biotech firms were chosen for this study because they are predominantly financed in welldefined stages or rounds by venture capital and have large fractions of their equity value in growth options. Biotech firms are highly dependent on the intellectual property (ideas, discoveries, patents) that they generate through their large R\&D expenditures, and as such are among the most intangible-intensive of businesses. The prototypical young biotech firm is in an intense $\mathrm{R} \& \mathrm{D}$ race against competitors to discover and patent a new drug. It therefore has large capital needs over a sustained period of time. In the early stages of life, the firm's capital needs are met by venture capital and strategic equity investments from pharmaceutical companies. However, capital needs eventually become so large that they can only be satisfied via an IPO or a buyout by a large pharmaceutical company. As a result, successful biotech firms tend to go public fairly quickly, so it is sometimes the case that a biotech firm's S-1 filing with the S.E.C. to contain financial statements that span its entire life. Having financial statement data through IPO filing documents is vital for assessing the empirical relations between the returns to venture capital investments and firm book-to-market ratios, because private companies rarely disclose firm book or asset values publicly outside of IPO filings, particularly when they are young.

\section{The risks and returns of venture capital investments}

\subsection{Prior literature on the relations between risk and return in venture capital}

Several papers have used fund-level data to examine the determinants of venture capital returns. Gompers and Lerner (1998) is the only study to examine the relations among firm size, book-to-market and returns in the pre-IPO market. They assess the relations between the quarterly excess returns on Warburg Pincus' marked-to-market private equity portfolio between 1972 and 1995 and the Fama-French factors. They report a beta of 1.27 and a significant loading on the SMB factor. ${ }^{1}$ Using Venture Economics data from 1980 to 2001, Kaplan and Schoar (2005, table VIII) calculate that venture fund IRRs have a beta of 1.07 with regard to the S\&P 500 , are increasing at a decreasing rate in the size of the fund, and are higher the larger was the prior fund raised by the venture capital group. Using an approach that compensates for the fact that fund quarterly returns contain current and stale company valuations, Woodward (2004) finds that the beta of venture capital between 1990 and 2003 is 2.0. Ljungqvist and Richardson (2003, table 10) analyze the IRRs over and above the return on the S\&P 500 of 73 private equity funds

\footnotetext{
${ }^{1}$ The SMB factor is the monthly difference between the return on small firms and the return on large firms. The HML factor is the monthly difference between the return on a portfolio of high book-to-market firms and the return on a portfolio of low book-to-market firms (Fama and French, 1993).
} 
that one of the largest institutional investors in private equity in the U.S. participated in between 1981 and 1993. They report that IRRs are increasing at a decreasing rate in fund size, and are worse the more money was raised in the fund's vintage year. Finally, Jones and Rhodes-Kropf (2004, table 2) employ Venture Economics data between 1980 and 1999 and report that venture capital funds have a beta of 1.11, load negatively on the HML factor, but do not load on the SMB factor. Jones and Rhodes-Kropf (2004) also predict and find that because of the sequential nature of the contracting negotiations between entrepreneurs and venture investors, venture capital returns will be correlated with total risk, not just systematic risk.

Other studies have used data at the level of the individual venture capital investment. Cochrane (2005) employs the VentureOne database to measure the standard deviation, alpha and beta of round-to-round and round-to-IPO returns to venture capital investments after applying an approach that aims to correct for the selection bias created by the greater availability of valuations for successful firms. Using VentureXpert data, Sarin et al. (2003) examine a large set of private equity financing rounds and find that the probability of exit, the valuation multiple, and the expected investment gain from a financing round depend on industry, firm stage-of-life, the financing amount, and the prevailing market sentiment.

As in Cochrane (2005), my study focuses on the narrowest measure of venture investment return, the round-to-round return earned between successive pre-IPO venture capital financings in a given company. However, I include an extensive set of controls for news about the firm's future cash flows that comes out during the return window. I also concentrate on one industry, the U.S. biotech sector. This allows me to examine the impact of firm size and book-to-market on venture returns within a reasonably homogenous setting, reducing the need to control for across-industry differences in production functions, growth options, and risk. The downside of focusing on the biotech sector is that I am less able to generalize the papers' main results and inferences beyond the biotech sector.

\subsection{The implications of existing theories for the pricing of firm size and book-to-market for round-to-round returns in pre-IPO venture-backed biotech companies}

In a seminal series of papers, Fama and French $(1992,1993,1996)$ report that firm size and book-to-market ratios supplant the CAPM beta in explaining variation in the expected returns to U.S. and international publicly traded stocks. Although much attention has been since been paid to understanding the reasons for their findings, there remains much disagreement as to why small firms and firms with high book-to-market ratios on average earn high expected returns. In this section I outline the main explanations and develop the predictions that each makes in the new setting of venture capital investments in pre-IPO biotech companies.

\subsubsection{Dynamic evolution of systematic risk as a consequence of optimal investments}

In a recent study, Berk et al. (1999) derive the implications for expected equity returns when aggregate firm risk is endogenously determined by a firm's optimal and dynamic exploitation of its growth options. Berk et al. assume that growth options are homogeneous in their expected cash flows, but heterogeneous in their beta risk. In their model, firms' assets turn over as some assets-in-place expire, new growth options with differing risk characteristics arrive, and firms 
respond optimally to those new growth options through their actual investment choices. The central feature of Berk et al.'s model is that firms that perform well tend to be those that have discovered valuable growth options. As these are exploited, the firm's systematic risk and mix of growth options to assets-in-place changes in predictable ways.

Berk et al. show that their model simplifies such that firm size and book-to-market become sufficient statistics for the aggregate risk of assets-in-place. That is, the state variables in the model can be eliminated, resulting in conditional expected returns being shown to be related to economically interpretable firm characteristics - specifically, firm size and book-to-market ratios. $^{2}$ Firm size is negatively related to expected returns because it is a proxy for the state variable that describes the importance of the firm's assets-in-place relative to its growth options. The book-to-market ratio is positively related to expected returns because it serves as a proxy for the state variable that summarizes the average systematic risk of assets-in-place. ${ }^{3}$

I argue that the Berk et al. model implies that firm size and market-to-book will be priced in the round-to-round expected returns of pre-IPO venture-backed biotech firms because biotech firms have large and rapidly evolving growth options and share a common technology (insofar as the risk profile of their growth options is concerned). They therefore match well with the type and maturity level of firms that Berk et al. argue will have returns that are heavily influenced by the dynamic exploitation of investment opportunities. ${ }^{4}$

\subsubsection{Financial distress risk}

Fama and French (1993) propose that the associations between firm size, book-to-market and returns arise because both firm size and book-to-market are proxies for non-diversifiable factor risk, specifically the risk that the firm will experience financial distress. Although this interpretation has not received uniform support (Dichev, 1998; Campbell et al., 2005), it is widely viewed as a leading explanation. Applied to the setting of pre-IPO biotech companies, the financial distress explanation predicts that pre-IPO biotech firms that are small and/or have high book-to-market ratios will earn high returns.

\subsubsection{Behaviorally biased investors}

Lakonishok et al. (1994) suggest that high book-to-market stocks earn high returns because investors in public markets are behaviorally biased. Their reasoning is that investors incorrectly

\footnotetext{
${ }^{2}$ The state variables in Berk et al.'s model are the average systematic risk of the firm's assets-in-place, the current risk-free rate, and the number of projects the firm is actively invested in.

${ }^{3}$ Carlson et al. (2004) derive the same directional predictions regarding the relations between expected returns, firm size and firm book-to-market using a different but complementary approach to that of Berk et al. Whereas Berk et al. hold expected cash flows constant but allow heterogeneity in investment risks, Carlson et al. hold project discount rates fixed but permit heterogeneity in expected cash flows via the state of product market demand conditions relative to invested capital. Other papers that have built on and complemented Berk et al.'s model include Gomes et al. (2003), Zhang (2004), and Anderson and Garcia-Feijóo (2006).

${ }^{4}$ Berk et al. note that their model captures the ideas that expected returns depend on the firm's life cycle, and that the returns of mature firms behave differently from those of growth firms (p.1566).
} 
extrapolate that the earnings of firms with poor past earnings growth rates (and therefore have high book-to-market ratios) will continue rather than regress to the mean. Lakonishok et al. suggest that such investors overreact by overselling those firms' stocks, making them underpriced and increasing the expected returns available to rational investors whose buying pressure subsequently moves stock prices back to the values implied by economic fundamentals.

Pre-IPO biotech firms are primarily financed by venture capital funds. As with mutual funds and hedge funds, venture funds have substantial resources at their disposal with which to hire the best and the brightest managers. I propose that this means that the general partners in venture funds will be sophisticated and experienced businesspeople that are not subject to behavioral biases. This proposition therefore predicts that there will be no relation between expected returns and book-to-market ratios in venture-backed pre-IPO firms.

\subsubsection{Data snooping}

Lo and MacKinlay (1990) and Black (1993) argue that repeated analysis on the same publicly traded stock return data means that 'anomalous' findings such as the pricing of firm size and book-to-market merely reflect in-sample data mining and/or misplaced reliance on classical statistics. The advantage offered by the setting examined in this paper is that the prior literature on the relations between firm size, book-to-market and returns in the pre-IPO market consists of only one study of one fund's private equity portfolio (Gompers and Lerner, 1998). As a result, the data snooping explanation for why firm size and book-to-market help explain variation in expected returns predicts that firm size and book-to-market will not be related to the expected returns of pre-IPO venture backed biotech companies because almost no snooping has occurred.

\section{A model of round-to-round returns in pre-IPO venture-backed biotech companies}

\subsection{Background}

The model of round-to-round venture capital returns that I use to evaluate the competing predictions laid out in Section 4 is derived from a log-linear specification of firms' underlying pre-money equity value. A firm's pre-money equity value at a given round of funding is the value of the firm's common plus preferred equity before the injection of new capital in that round. Also known as hedonic modeling, the log-linear approach to equity valuation is standard in entrepreneurial finance (Lerner, 1994; Gompers and Lerner; 1999, 2000a, b; Seppä, 2003; Hand, 2005). The method proposes that firm value is a log-linear function of plausible proxies for the dividends, free cash flows or net incomes that firms may generate far ahead into their futures. It is used instead of more exact valuation methods such as discounted cash flows, free cash flows or residual income because not only do pre-IPO venture-backed firms never pay dividends, but the vast majority of the equity value of venture-backed firms is attributable to their growth options rather than assets-in-place. As such, summary accounting measures of ex-post performance such as net income are typically uninformative about equity value.

\subsection{Valuation framework}

The valuation framework underlying the model of realized round-to-round returns that I 
empirically estimate is illustrated as follows. Consider a three-period world. At point in time $\mathrm{t}=0$ the firm is founded with an initial capital investment. The terminal payoff to that investment, $X$, is random and will be realized at $\mathrm{t}=3$. At $\mathrm{t}=1$, the firm's pre-money value is therefore:

$$
P R E M V_{1}=\frac{\mathrm{E}_{1}\{X\}}{\mathrm{E}_{1}\left\{R E T_{12}\right\} \times \mathrm{E}_{1}\left\{R E T_{23}\right\}},
$$

where $\mathrm{E}_{1}\{X\}$ is the expected value of $X$ conditional on information at $\mathrm{t}=1$ and $R E T_{\mathrm{jk}}$ is one plus the stochastic rate of return between $\mathrm{t}=\mathrm{j}$ and $\mathrm{t}=\mathrm{k}$. Following the method of hedonic modeling, $\mathrm{I}$ assume that $\mathrm{E}\{X\}$ is a Cobb-Douglas function of multiple proxies for $X$, denoted by $Y$ and $Z$ :

$$
\mathrm{E}_{1}\{X\}=e^{\alpha} Y_{1}^{\beta} Z_{1}^{\gamma}
$$

where $Y_{1}$ denotes the value of $Y$ at $\mathrm{t}=1$. Substituting equation (2) into equation (1) and taking natural logarithms yields:

$$
\ln \operatorname{PREMV}_{1}=\alpha+\beta \ln Y_{1}+\gamma \ln Z_{1}-\ln \left[\mathrm{E}_{1}\left\{R E T_{12}\right\}\right]-\ln \left[\mathrm{E}_{2}\left\{R E T_{23}\right\}\right]
$$

If no additional investment is made in the firm at $\mathrm{t}=1$, and if new information arriving between $\mathrm{t}=1$ and $\mathrm{t}=2$ does not change the expectation of $R E T_{23}$ so that $\mathrm{E}_{1}\left\{R E T_{23}\right\}=\mathrm{E}_{2}\left\{R E T_{23}\right\}$, then the $\log$ realized return between $\mathrm{t}=1$ and $\mathrm{t}=2$ is equal to the $\log$ change in PREMV: ${ }^{5}$

$$
\ln R E T_{12}=\ln \left[\frac{P R E M V_{2}}{P R E M V_{1}}\right]=\ln \left[\mathrm{E}_{1}\left\{R E T_{12}\right\}\right]+\beta \ln \left[\frac{Y_{2}}{Y_{1}}\right]+\gamma \ln \left[\frac{Z_{2}}{Z_{1}}\right]
$$

Equation (4) says that the $\log$ realized return between $t=1$ and $t=2$ equals the $\log$ expected return between $\mathrm{t}=1$ and $\mathrm{t}=2$, adjusted for news about the level of the terminal payoff. Finally, if the expected return is assumed to be a linear function of firm size (FSIZE) and book-to-market $(B T M)$, then equation (4) can be rewritten as:

$$
\ln R E T_{12}=\delta+\pi \ln F S I Z E_{1}+\phi \ln B T M_{1}+\beta \ln \left[\frac{Y_{2}}{Y_{1}}\right]+\gamma \ln \left[\frac{Z_{2}}{Z_{1}}\right]+e
$$

where $e$ is the error term that is assumed to capture the difference between $\ln \left[\mathrm{E}_{1}\left\{R E T_{12}\right\}\right]$ and $\delta+\pi \ln F S I Z E_{1}+\phi \ln B T M_{1}$. Equation (5) forms the theoretical basis for my empirical tests.

\subsection{Empirical specification}

\footnotetext{
${ }^{5}$ The assumption that new information arriving between $\mathrm{t}=1$ and $\mathrm{t}=2$ does not change the expectation of $R E T_{23}$ such that $\mathrm{E}_{1}\left\{R E T_{23}\right\}=\mathrm{E}_{2}\left\{R E T_{23}\right\}$ is undeniably a strong one. In the empirical tests, I aim to control for the mean effects of departures from this assumption via indicator variables that reflect when the Series number of round $k$ differs from the Series number of round $k-1$.
} 
The round-to-round returns model that I estimate fleshes out equation (5) in several ways. First, I replace raw returns with excess returns by subtracting from raw returns the risk-free return over the return horizon. Second, consistent with Fama and French (1992) and Berk et al. (1999), I employ the firm's pre-money value at the beginning of the return window as my measure of firm size. Third, I use total assets at the beginning of the return window rather than book equity in computing the book-to-market ratio. The reason is that book equity is negative in $46 \%$ of my sample observations, primarily due to accounting rules requiring that R\&D and other intangible costs be expensed rather than amortized over time into income. Accounting rules therefore greatly downward bias the shareholder equity of firms such as young biotech companies whose expenses consist almost entirely of investments in intangibles. Fama and French (1992, table III) report that they obtain very similar inferences in the public equity market if book-to-market ratios are computed using total assets instead of book equity.

Fourth, I use a broad variety of different proxies for the firm's future cash flow payoffs. They include sector-wide data, denoted BIO (e.g., the level of the AMEX biotech sector index); firm-specific financial statement data, denoted FS (e.g., cash, revenues, R\&D spending); firmspecific non-financial statement data, denoted NFS (e.g., patent filings and strategic alliances); investor-specific indicator variables, denoted INVIND (e.g., the type of lead investor in a given financing round); and indicators for the Series number of the financing round, denoted SERIND (e.g., Series A, Series B, etc.). Full details on these variables are provided in Section 6. Financial statement variables are in $\$ 000$ s prior to being log-transformed, and variables that can take a value of zero are rescaled by adding +1 to the variable for each observation in the sample (e.g., zero revenue is rescaled to $\$ 1,000$, and $\$ 39,000$ of revenue is rescaled to $\$ 40,000$ ).

Fifth, I generalize equation (5) by taking into account the investment that venture investors make at the round that marks the beginning of the round-to-round return window. To see this, note that PREMV is the product of the number of pre-money shares outstanding, SHSPRE, and the pre-money price per share, PRICE. Thus the log change in pre-money valuation between adjacent financing rounds $k-1$ and $k$, denoted $\triangle \ln P R E M V_{i k}$, is the sum of the round-to-round $\log$ return $\ln \left[R E T_{i k}\right] \equiv \ln \left(P R I C E_{i k} / P R I C E_{i, k-1}\right)$ and the round-to-round log change in pre-money shares outstanding $\triangle \ln P R E M S H S_{i k} \equiv \ln \left(S H S P R E_{i k} / S H S P R E_{i, k-1}\right)$. With this in mind, I generalize equation (5) by including $\triangle \ln P R E M S H S_{i k}$ as an additional explanatory variable, although without constraining its coefficient to equal -1 .

Last but by no means least, I include Heckman's (1979) inverse Mills ratio, denoted MILLS, in the pre-money valuation equation as a first-pass control for the endogeneity biases that may arise from restricting the sample to only the most successful venture capital investments - viz., those that filed to go public. This leads to the inclusion of $\triangle M I L L S$ in the round-to-round returns model. In section 8.4 of the paper I explore a non-Heckman approach to assessing the potentially distortive inferential impacts of sample selection biases.

In total, these adjustments lead to the following empirically testable version of equation (5): 


$$
\begin{aligned}
& \ln \operatorname{EXRET}_{i k}=\delta+\pi \ln P R E M V_{i, k-1}+\phi \ln B T M_{i, k-1}+\sum_{b} \beta_{b} \Delta \ln E_{X B I Q_{i k}} \\
& +\sum_{c} \theta_{c} \Delta \ln F S_{c i k}+\sum_{d} \gamma_{d} \Delta \ln N F S_{d i k}+\sum_{e} \pi_{e} \Delta I N V I N D_{e i k}+\sum_{a} \phi_{a} \Delta S E R I N D_{a i k} \\
& +\kappa \Delta \ln \text { PREMSHS }_{\text {ik }}+v \Delta M I L L S_{k}+e_{i k}
\end{aligned}
$$

where $i$ denotes firm $i$ and $E X R E T_{i k}$ is the excess return between financing rounds $k-1$ and $k$. Because the round-to-round return from the last round of venture funding is earned at the IPO, equation (6) covers both round-to-round returns earned purely within the venture capital market, as well as the round-to-round return earned between the last venture round and the IPO.

\section{Data}

The data used in this study is a synthesis of pre-money equity valuations in the venture capital market and at the IPO filing date, characteristics of venture investors, firm-specific annual financial statement data, and firm-specific non-financial statement information (Hand, 2005). These variables are collected for 203 U.S. biotech companies over the period 1992-2001. The core of the dataset is a merging of the historical annual financial statement data reported in biotech firms' IPO filings with the time-series of those same firms' pre-money venture capital and at-IPO equity values. On a firm-by-firm basis, each year's financial statements are matched where possible with the first - and only the first - pre-money valuation following the fiscal yearend, providing that the valuation date was less than a year after the fiscal year-end. No set of annual financial statements was matched with more than one pre-money valuation. This process yielded 481 pairs of pre-money venture capital valuations and 103 pre-money at-IPO valuations for which there were financial statements from the preceding fiscal year, covering a total of 203 firms. To be usable, a firm's cash balance, SG\&A expense, and R\&D expense had to be positive. ${ }^{6}$ The dataset contains 381 pre- plus at-IPO round-to-round returns spanning 182 firms.

I now turn to describe the data and variables used in equation (6). A description of the model used to estimate MILLS, the Heckman inverse Mills ratio, is deferred until Section 7.

\subsection{Equity valuation data}

Pre-money equity valuations were purchased from Recombinant Capital (Recap), a West Coast consulting firm that specializes in collecting and selling information on biotech companies (www.Recap.com). Recap has gathered a full set of the round-by-round financings of over 600 biotech companies, beginning in the early 1980s. Recap's equity valuation histories are mainly compiled from IPO S-1 and 424B filing documents and the SEC filings of companies that acquired biotech firms. The valuation histories are based on primary preferred and common share issuances from the date of founding through the IPO filing. Preferred shares are converted into common equity at the ratios specified in the financing agreements. The vast majority of financings undertaken by venture capitalists are in the form of preferred stock.

\footnotetext{
${ }^{6}$ Although some biotech firms report zero revenues, biotech firms that have no cash, or no SG\&A, or no spending on $R \& D$ are very unusual. Approximately $2 \%$ of observations were deleted as a result of these restrictions.
} 
Relative to other sources of pre-money values such as VentureOne and VentureXpert, one of Recap's distinctive features is that for each financing round it reports the price per share, PRICE, the number of pre-money shares outstanding, SHSPRE, and the number of shares issued in the financing, SHSISS. As a result, round-to-round returns can be computed directly, rather than having to be inferred from pre-money valuations at round $k$ relative to post-money valuations at round $k-1$. The log return of firm $i$ between venture capital funding rounds $k-1$ and $k$ is $\ln R E T_{i k}$ $\equiv \ln \left(P R I C E_{i k} / P R I C E_{i, k-1}\right)$, and the excess $\log$ return $\ln E X R E T$ is $\ln \left[R E T-R_{f}\right]$, where $R_{f}$ is one plus the risk free rate over the return interval.

\subsection{Sector-wide data}

I use the AMEX Biotechnology Index as a proxy for the prospects of firms in the biotech sector. Lerner (1994) shows that the level of publicly traded biotech stocks is strongly positively related to the pre-money values of venture-backed biotech firms.

\subsection{Financial statement data}

For those firms in Recap's database that filed to go public, pre- and at-IPO financial statement data were collected from S-1 and 424B documents when available online at www.sec.gov. Firms that file to go public have to provide five years' worth of audited (albeit somewhat coarse) historical financial statement data.

The financial statement items whose log changes are included in equation (6) consist of the key components of young biotech firms' balance sheets and income statements - namely cash, noncash assets, long-term debt, revenues, and R\&D expense. ${ }^{7}$ Long-term debt includes capitalized lease obligations. Revenue is the sum of collaborative, contract, grant, license, research, and product revenues. The economic nature of these items predicts that the level (growth rate) of all but long-term debt will be positively related to firms' pre-money values (round-to-round returns). Since it is a liability, the level (growth rate) of long-term debt should be negatively related to firms' pre-money values (round-to-round returns). In addition to these items that accounting rules explicitly require firms to record in financial statements, I also include the unrecorded or off-balance sheet amount of stock option dilution in the set of financial statement items. Stock option dilution is defined as the number of shares under option divided by the number of shares outstanding. Stock option data are sometimes missing because firms are only required to provide three years of pre-IPO-filing stock option data in their S-1 or 424B filings. To account for this, an indicator variable is included in the regressions, set equal to one if stock option data are missing and zero otherwise. After the indicator variable was computed, missing stock option dilution observations were reset to zero. The economic nature of stock option dilution predicts that the level (growth rate) of stock option dilution will be negatively related to firms' pre-money values (round-to-round returns).

\subsection{Non-financial statement information}

\footnotetext{
${ }^{7}$ Cost of sales is excluded because it is only non-zero when the biotech firm has product revenues, which is rare. Selling, general and administrative expenses, although material in size, are not included for reasons of parsimony.
} 
Prior research into pre-IPO biotech firms has found that the number and scope of the patents filed by the firm, and the number of its strategic alliances with pharmaceutical companies or other biotech firms are associated with venture capital pre-money valuations. Patents are a key mechanism by which young biotech firms create legally defensible property rights on their intellectual innovations and property. As such, they have been seen as biotech companies' most valuable assets. Lerner (1994) finds that pre-money values are higher the more patents a firm has filed or has been granted and the more focused is the scope of the firm's patent portfolio. The number of patents filed with the U.S. Patent Office as of the pre-money valuation date was collected online from www.uspto.gov. Following Lerner (1994), patent scope is defined as the cumulative number of distinct four-digit International Patent Classification classes into which a firm's filed patents are assigned, divided by the number of patents that it had filed for.

Alliances with pharmaceutical companies and other biotech companies provide credible endorsements of the quality of a biotech firm's scientific pipeline and management. They also create value for the firm by taking advantage of the particular business and technical expertise held by the alliance partners (Lerner and Merges, 1998). Nicholson et al. (2005) report that biotech companies that sign strategic alliance deals with other biotech or pharmaceutical companies receive higher pre-money valuations. Data on the number of strategic alliances come from Recap's alliance database.

Separate from these firm-specific items of non-financial statement information whose correlations with pre-money values have been explored by prior work, I examine the effect of firm-specific demand on round-to-round venture capital returns. In a perfect market, the demand for any single firm's equity is perfectly elastic because there is a perfect substitute available and there are no market frictions. However, Gompers and Lerner (2000b) show that this is not the case in the illiquid and incomplete venture capital market. They find that the pre-money valuations of venture-backed firms are reliably increasing in the aggregate inflows of capital into venture funds. I extend Gompers and Lerner's work in this regard by using a firm-specific proxy for equity demand in place of the aggregate inflow of capital into venture funds. The proxy is the dilution created by the current financing round, defined as the ratio of the number of shares issued in the current round divided by the number of pre-money shares outstanding. If demand for a firm's equity is less than perfectly elastic, then there will be a negative relation between dilution (growth in dilution) and firms' pre-money values (round-to-round returns).

\subsection{Investor-specific characteristics}

Gompers and Lerner (1999) find that corporate investors assign higher pre-money valuations to firms than do private equity funds, either because corporations perceive there to be strategic synergies available, or because corporations engage in less monitoring and business development than do private equity funds and therefore require a lower expected return on their investment. For each financing round, Recap identifies whether or not the lead investor is a corporation. Based on this, I create two indicator variables. The first is set to one if round $k$ is led by a corporate investor, and the second is set to one if round $k-1$ is led by a corporate investor. Based Gompers and Lerner's findings, I expect to observe that in a round-to-round returns regression the coefficient on the former will be positive while the coefficient on the latter will be negative. 
I also create a new investor-specific indicator that is set to one if the name of the lead venture investor in round $k$ is the same as that in round $k-1$ (regardless of whether the lead investor is a corporation or a venture capital fund). The coefficient on this indicator is predicted to be positive because a strong performance by the firm between rounds $k$ and $k-1$ would seem likely to result in round $k-1$ 's lead investor exploiting the preemptive rights and anti-dilution protections granted to him in round $k-1$ and taking the lead investor position again in round $k^{8}$

\subsection{Financing round Series indicators}

The set of Series indicators, SERIND, consists of seven dummy variables covering financing rounds Series A through Series $\geq F$, plus the IPO itself. For example, if round $k$ is a Series B round, then $S E R I N D_{B}=1$, else $S E R I N D_{B}=0$. In equation (6), $\triangle S E R I N D$ are more accurately described as step-up indicators that take the value one if round $k$ is of a higher level than round $k-1$. For example, if round $k$ is a Series $C$ round but round $k-1$ is a Series B round, then $\triangle S E R I N D_{C}=1$. It is not automatic that $\triangle S E R I N D_{C}=1$ because a firm may have two sequential rounds of Series B funding (usually denoted Series B-1 and B-2). Unlike other databases, Recap codes the Series of the financing round-whether the round is Series A, Series B, etc.- - rather than the life-stage of the firm (e.g., startup, product development, shipping, profitable, etc.).

\section{Descriptive statistics}

Table 1 reports descriptive statistics for the sample. Venture capital financings occur over the period 1992-2001, while IPO dates occur over the shorter interval 1995-2001 (panel A). Most biotech firms file to go public four to six years after they were founded (panel B). The IPO filing date for the median firm occurs during preclinical testing or phase I trials, although a few firms take much longer to file to go public. Most sample companies are in pharmaceutical preparations (SIC 2834) or commercial, physical and biological research (SIC 8731). Despite this concentration, sample firms comprise a total of 22 different 4-digit SIC codes. Of firms, 47\% had their headquarters in California at the time of the IPO filing and 14\% were in Massachusetts. Headquarter clustering arises because California and Massachusetts have many top universities with star scientists on their faculties (Zucker et al., 1998).

Table 2 provides a more detailed description of venture-backed firms, in which the median values of key variables are listed on a round-by-round basis from left to right in the typical sequence followed by a venture-backed firm, beginning with the Series A funding round and ending with the IPO filing. The number of observations at a given round differs from the number of firms in the sample because some sample firms filed to go public after their Series B round but others not until after their Series H round. Also, each set of annual financial statements is only ever matched to one financing round. Table 2 excludes financings not explicitly coded by Recap

\footnotetext{
${ }^{8}$ Admati and Pfleiderer's (1994) fixed-fraction contract theory supports this prediction in that it explains why the granting of pre-emptive rights and anti-dilution protections are optimal with respect to resolving various agency problems that arise in a multistage financial contracting situation of the kind encountered by venture investors.
} 
as being Series A, Series B, etc. ${ }^{9}$

Pre-money valuations increase as firms mature within the venture capital market at a decreasing rate but then double at the IPO (Table 2). Round-to-round returns typically decline as firms mature, although the mean return between the round prior to the IPO and the IPO is a very large $159 \%$. The median values of all financial statement items increase as firms mature, except core income which decreases because biotech firms have small revenues but large expenditures on SG\&A and R\&D. Book-to-market ratios remain low during the time that firms are private venture-backed entities. Of the 584 observations, only $1 \%$ have a book-to-market ratio greater than one. Consistent with firms' growth opportunities being converted into assets-in-place as firms mature, the median ratio of assets-in-place to pre-money equity value increases from 0.10 at Series A rounds to 0.20 at Series F rounds, although the median ratio drops at the IPO to 0.15.

Average firm age tends to rise as the funding Series increases. The median gap between the date on which the pre-money valuation is established and the end of the preceding fiscal year is always four months or less, and is smallest for Series A and largest for the IPO. The proximity in time of the financial statements to the valuation date mitigates the potential concerns that financial statement data are stale by the time the firm's current round of financing is undertaken and are staler the earlier the round. Equity dilution created at the current financing round declines from a high of $46 \%$ in Series A rounds to $17 \%$ in Series $\geq F$ rounds, while the probability that the lead investor is a corporation steadily increases. The median number of patents filed and issued and the number of strategic alliances steadily increase as firms mature.

\section{Regressions}

\subsection{Heckman correction for potential selection bias}

A key concern in estimating equation (6) is that conditioning on firms that filed for an IPO will lead to biased coefficient estimates. For example, restricting the set of all round-to-round returns to only those for which the most successful investment outcome was ultimately achieved - that is, an IPO - may well induce a negative loading on the firm size factor in the round-to-round returns model. I therefore include in the regressions an estimate of Heckman's (1979) inverse Mills ratio, denoted MILLS, with the goal of controlling for coefficient distortions that may be created by this kind of selection bias. Using VentureOne data on venture funding undertaken by U.S. biotech companies over the period 1985-2002, I estimate MILLS from the following Probit selection equation:

$$
\begin{aligned}
\text { IPOIND }_{i k}=\zeta & +\sum_{a} \pi_{a} \text { SERIND }_{a i k}+\Omega_{1} \ln \text { RAISED }_{i k}+\Omega_{2} \ln \text { BIOPUB }_{i k} \\
& +\Omega_{3} \text { CORPIND }_{i k}+\Omega_{4} \text { CALIFIND }_{i k}+\Omega_{5} \text { MASSIND }_{i k}+\varsigma_{i k}
\end{aligned}
$$

\footnotetext{
${ }^{9}$ Such financings include investments of common equity, private placements, and debt-related financing such as bridge and convertible notes. These can occur anywhere in the firm's pre-IPO life, whereas a given firm's Series C financing always follows after its Series B financing, etc.
} 
where IPOIND $D_{i k}=1$ if firm $i$ had filed to go public as of 12/31/02, zero otherwise; SERIND $D_{a}$ are the same Series indicators as in equation (6); $\ln R A I S E D_{k}$ is the log of the amount of capital raised in round $k$ (in $\$ 000$ s prior to being log-transformed); $\ln B I O P U B$ is the log of the AMEX Biotechnology index at the financing date; CORPIND ${ }_{k}=1$ if the lead investor in round $k$ was a corporation; and CALIFIND and MASSIND are indicators set to one if the firm had a California or Massachusetts headquarters, respectively. Equation (7) contains no other firm-specific data of the kind included in the pre-money valuation or round-to-round returns models because the data obtained from VentureOne did not identify firms by name, only by a code number.

The inverse Mills ratio is computed as MILLS $=\phi\left(b^{\prime} X\right) / \Phi\left(b^{\prime} X\right)$, where $\phi($.$) and \Phi($.$) are$ the normal probability density and the normal cumulative density functions, respectively, and $b$ and $X$ are the vector of estimated coefficients and the matrix of independent variables in equation (7), respectively. In equation (7), I expect the coefficients on Series indicators to be larger the higher is the funding series round (reflecting the higher likelihood of filing for an IPO as the firm matures) and that $\Omega_{1}>0$ (with more funding rationally reflecting more confidence by venture capitalists of the ultimate success of the firm). I also predict that $\Omega_{3}>0, \Omega_{4}>0$, and $\Omega_{5}>0$ based on the findings of Gompers and Lerner (2000a, Table 5.4). For a similar type of model estimated on all venture-backed firms in VentureOne's database between 1983 and 1994, Gompers and Lerner find that firms are more likely to go public if the financing round is led by a corporate investor, and if the firm is headquartered in California or Massachusetts. Finally, there are conflicting predictions for $\Omega_{2}$. If higher market-wide valuations reflect rational expectations of the prospects for the biotech industry, then higher market-wide valuations should imply a higher probability that a firm will file to go public. However, if higher levels of market-wide valuations reflect overvaluation of the sector, then the reverse will apply, assuming that the overvaluation dissipates over time.

The results of estimating equation (7) are reported in Table 3. As expected, the amount of funding is positively related to the firm eventually filing to go public. However, having a corporate lead investor or a firm headquartered in California does not increase the probability that the firm will file to go public, and being headquartered in Massachusetts is reliably negatively - not positively - associated with the probability of filing to go public. The coefficient estimates on the logs of the AMEX biotech index is reliably negative, suggesting that higher levels of market-wide valuations are indicative of over-valuation of the biotech sector.

\subsection{Pre-money value regressions}

Before proceeding to the round-by-round returns regressions that are the focus of this paper, Table 4 reports the results of estimating a log-linear model of firms' pre-money equity values. Although the regression estimated in Table 4 differs from the one proposed in equation (3) - by virtue of omitting terms for expected returns - it does provide a connection to the literature in entrepreneurial finance that has estimated the same general types of log-linear models.

Given the atypical features of the IPO round suggested by Table 2's descriptive statistics and the potential concern that the IPO round lies somewhere between a fully private and a fully public equity market, I estimate two regressions: one for all pre-IPO and at-IPO rounds combined together, and as a robustness test, one for only pre-IPO rounds. The pooled time-series 
cross-sectional nature of the data means that regression errors may not be homoscedastic or serially independent. I therefore estimate all regressions using Newey and West's (1987) covariance matrix and Hansen's (1982) GMM approach. The GMM approach accommodates serial dependence and conditional heteroscedasticity in the residuals and has a small loss of precision relative to OLS, should errors in fact be homoscedastic and serially uncorrelated. Inferences are unaffected if OLS standard errors are used. Although Series indicators are in the regressions, for parsimony I do not report those coefficients or the intercept in Table 4.

The results in Table 4 generally match well with expectations and prior research. I discuss only the all-rounds results, as the results for just the pre-IPO funding rounds are similar. In the all-rounds sample, 10 of the 15 coefficients have signs that are reliably in the predicted direction. The coefficient on the AMEX public market biotech index is reliably positive as predicted. With the exception of revenues, the coefficients on the firm-specific financial statement data are all significant in the predicted directions. The coefficients on firm-specific non-financial statement information are more mixed. On the one hand, firms' pre-money equity values are reliably decreasing in the degree of new equity dilution created at the financing round and reliably increasing in the number of the firm's strategic alliances. On the other hand, the coefficient on the number of patents a firm has filed is insignificant, and the coefficient on the scope of patents filed is significantly negative, opposite sign to what was predicted. ${ }^{10}$ The inverse Mills ratio is reliably negative as expected. While results are strongest and most consistent for pre-IPO rounds, not dissimilar results obtain for the smaller at-IPO sample.

\subsection{Round-to-round returns regressions}

The results of estimating the round-to-round returns model proposed in equation (6) are reported in Table 5. As in Table 4, I estimate two regressions: one for all pre-IPO and at-IPO rounds combined together, and as a robustness test, one for just pre-IPO rounds. In both regressions, round-to-round excess returns are reliably negatively related to firm size and positively related to firm book-to-market ratios. In the all-rounds model, the estimated coefficient on firm size is -0.16 (GMM Z-statistic $=-6.1$ ) while that on book-to-market is 0.12 (GMM Z-statistic = 3.6). The size of these coefficients implies that at the means of the independent variables, a one standard deviation increase in log firm size leads to a decrease in the average round-to-round return of $20 \%$, while a one standard deviation increase in log bookto-market increases the average round-to-round return by $18 \%$.

The reliably negative pricing of firm size and positive pricing of book-to-market strongly conform to the predictions made by Berk et al.'s (1999) theory in which the endogenous relations between growth options, optimal investment actions and expected returns lead to firm size and book-to-market are sufficient statistics for the aggregate risk of a firm's assets-in-place. Following the reasoning presented in section 4.2, they are less consistent with the predictions made by Lakonishok et al.'s (1994) behaviorally biased investors explanation for why firm size

\footnotetext{
${ }^{10}$ Lerner (1994) finds a reliably negative valuation coefficient on the scope of patents filed. It may be that the economics of patent protection may have changed over time such that it is now more valuable to hold a portfolio of narrowly scoped patents, rather than broadly scoped ones. Lerner's sample (1973-1992) and mine (1992-2001) do not overlap in time, making this at least possible.
} 
and book-to-market are priced in the cross-section of expected returns, and the data snooping explanation proposed by Black (1993) and Lo (1994).

Insofar as Fama and French's (1993) explanation is concerned, the signs on firm size and book-to-market are consistent with their theory that firm size and book-to-market are proxies for financial distress risk. However, as shown in Table 2, pre-IPO biotech firms have very low, not high, book-to-market ratios. The median book-to-market ratio in my sample is only 0.17 , far lower than the median value of 1.26 for all publicly traded firms over the sample period. ${ }^{11}$ Such low levels of book-to-market ratios appear inconsistent with the proposition that book-to-market are a proxy for the risk of financial distress. In this sense, the pricing of round-to-round returns for pre-IPO biotech firms is partly, but not fully consistent with Fama and French's explanation.

Beyond the pricing of firm size and book-to-market, Table 5 reveals that the realized roundto-round excess returns to pre-IPO venture-backed companies are sensitive to a wide variety of news. First, round-to-round excess returns are positively related to the excess returns of publicly traded biotech firms. For example, in the pre-IPO + at-IPO regression, the estimated beta of 0.85 on the AMEX biotech index lies between the beta of 0.3 reported by Cochrane $(2005$, table 4$)$ on the S\&P500 index, and the beta of 1.45 reported by Cumming and Walz (2004, table 4) on the Morgan Stanley Capital International index.

Second, returns are positively related to news about three firm-specific financial statement items (firms' cash balances, noncash assets, and R\&D expenditures) and are negatively related to news concerning two firm-specific non-financial statement variables (the dilution created at financing dates and the round-to-round growth in shares). Round-to-round returns are also related to news about two investor-characteristics: returns are reliably higher if the lead investor in the current financing round is a firm rather than a venture fund, but, contrary to expectations, returns are lower if the lead investor in the current round is the same as in the previous round.

\subsection{Robustness tests}

The most important robustness issue is whether the estimated inverse Mills ratio in Tables 4 and 5 successfully controls for selection biases. To the extent that it is not, inferences made in section 8.3 - particularly those dealing with the pricing of firm size and book-to-market ratiosmay be wrong. I therefore try to measure the effects of selection bias in different ways.

\subsubsection{Omitting the inverse Mills ratio}

In unreported tests, I estimated the regressions reported in Tables 4 and 5 after omitting the inverse Mills ratio computed from Table 3. No major inferences changed. In particular, the pricing of firm size (book-to-market) in returns in Table 5 remains reliably negative (positive).

\subsubsection{A non-Heckman approach to evaluating the effects of selection bias}

The ideal biotech dataset would be one that contained all the independent variables used in Table 5 for all the round-to-round returns for all venture-backed biotech firms regardless of their

\footnotetext{
${ }^{11}$ As noted in Section 5.3, the book measure that I employ is total assets, not shareholder equity.
} 
ultimate status. This would yield no selection biases on regression coefficients. Unfortunately, this database does not exist because firms are far less likely to disclose or "make visible" their firms' valuations at financing rounds that occur at what they believe are low prices, and financial statement data is only systematically available and visible for firms that file to go public.

Along the valuation dimension, the closest thing to the abovementioned ideal biotech dataset is Sand Hill Econometrics' health sector catalog of firm valuations and financings. This meticulously constructed dataset is the deepest and most comprehensive set of valuations for U.S. venture-backed companies available to date. The version used in this study contains preIPO firms' valuation histories including the valuation at the ultimate exit of the company, if there was one, as of May 2004. Sand Hill codes exit events as falling into one of four exhaustive categories: the firm went public; the firm was acquired; the firm went out of business, or the firm is still in business as a private company.

I exploit the likely minimal presence of exit-based selection biases in Sand Hill's database by estimating on it a restricted version of Table 5's round-to-round returns model. Relative to the model estimated in Table 5, the model estimated and reported in Table 6 includes only three independent variables - firm (pre-money) size, the return on the AMEX biotech index, and the growth in new equity dilution created at the beginning and end of return window financing rounds. The Table 6 model is therefore restricted relative to the Table 5 model. First, the Sand Hill database does not contain firms' book values, so a book-to-market variable cannot be constructed. Second, of the firm- and investor-specific variables in Table 5's regressions, only new equity dilution is in or can be computed from the Sand Hill database. Third, the Sand Hill database contains only visible round-to-round returns - that is, returns computed from consecutive rounds for which both a post-money value is available or 'visible' at round $k-1$ and a pre-money value is visible at round $k$. Finally, for simplicity I use raw rather than excess returns.

Panel A of Table 6 summarizes the ultimate status of the firms in Sand Hill's database for which at least one visible round-to-round return and all three of the required independent variables were available. Of the 1,669 round-to-round returns, 44.7\% were associated with firms that as of May 2004 had gone public, 13.9\% were associated with firms that were acquired, 5.7\% were associated with firms that had gone out of business, and 35.7\% were associated with firms that were still private and in business. Since firms can go out of business without losing $100 \%$ of equity value, I ascribe a uniform return of $-90 \%$ to all round-to-round returns that were coded as ending at the round where the firm went out of business.

Panel B of Table 6 reports two sets of regression results. The first are for the Sand Hill database, while the second are from estimating the same regression plus the round-to-round change in the Inverse Mills ratio on the all-rounds data used in Table 5. The results for the Sand Hill database are consistent with the proposition that in the absence of conditioning on the ultimate status of the firm, firm size is reliably negatively priced in (visible) round-to-round returns. Also, as in Table 5, the public market beta is reliably positive and the coefficient on the growth in new equity dilution is reliably negative. The results for the all-rounds data used in Table 5 are very similar. This indicates that although the model estimated in Table 6 is a highly restricted version of the model estimated in Table 5, it is not so restricted as to yield different inferences on the independent variables that are common to both models. 
The results in Table 6 therefore suggest that the negative pricing of firm size found in Table 5 is not due to the coefficient on firm size being biased because the sample used in Table 5 conditions on only firms that were successful enough to file to go public. I therefore cautiously conclude while it cannot be ruled out that the results on the pricing of firm size, firm book-tomarket and news-related variables found in Table 5 are a spurious result of selection biases, the Heckman controls included in Table 5 together with the test results reported in Table 6 seem to indicate that selection biases may not be a major source of inferential risk.

\subsection{Other robustness tests}

Beyond the selection bias issues just addressed, the results reported in Tables 4 and 5 are robust to a variety of perturbations. For example, similar results obtain if firm size is measured using total assets or a firm's post-money value at round $k-1$, or if the log of the ratio of long-term debt to equity value is added to control for the "missing" portion of book equity that is excluded by defining book-to-market ratios using total assets rather than shareholder equity. No differences in inference arise if the regressions include indicator variables for the main four-digit SIC codes 2834, 2836 and 8731, or indicators for firm headquarters' location in California or Massachusetts. Taking into account the varying lengths of the return windows by including the length of the return window as an additional explanatory variable has immaterial effects on the estimated regression. Inferences also remain unchanged if rank regressions are estimated.

\subsection{Caveats and limitations}

Beyond the uncertainty as to the generalizability of results derived from only biotech firms, it may be that my inferences are biased due to correlated omitted variables. Although this study has gone to some length to include variables found by prior work to be relevant to the values and returns of venture-backed firms, there may still be factors omitted that are materially correlated with the included variables, therefore biasing the inferences that have been made.

\section{Conclusions}

In this paper I proposed that pre-IPO venture-backed biotech companies offer a productive new setting through which to shed light on competing theories of why firm size and book-tomarket explain variation in expected stock returns. This is because pre-IPO biotech firms have very large and rapidly evolving growth options relative to assets-in-place. Such attributes align closely with the key features of Berk et al.'s (1999) theory of the endogenous relations between growth options, optimal investment actions and expected equity returns, where firm size and book-to-market emerge as sufficient statistics for the aggregate risk of a firm's assets-in-place.

Using venture capital investments in pre-IPO U.S. biotech companies during 1992-2001, I found that equity returns between financing rounds are reliably negatively related to firm size and positively related to book-to-market ratios. After undertaking both Heckman and nonHeckman approaches to evaluating the potential inferential distortions arising from selection biases (in that I am only able to use firms that were the most successful, those that went public), I concluded that my results are probably not due to selection bias. Instead, I conclude that the 
negative pricing of firm size and the positive pricing of book-to-market are most consistent with Berk et al.'s theory as well as being somewhat inconsistent with the alternative explanations of financial distress, behaviorally biased investors, and data snooping. I also found that realized returns are affected by a wide variety of sector-wide, firm-specific and investor-specific news. Taken together, the results of this paper suggest that notwithstanding the unusual features of the venture capital market, venture capital investors sensibly incorporate a great deal of relevant information into firms' equity prices when they invest new capital. This would seem to bode well for the extent to which the U.S. venture capital allocates scarce capital. 


\section{References}

Admati, A.R., Pfleiderer, P. 1994. Robust financial contracting and the role of venture capitalists. Journal of Finance 49(2): 371-402.

Anderson, C.W., Garcia-Feijóo, L. 2006. Empirical evidence on capital investment, growth options, and security returns. Journal of Finance, forthcoming.

Berk, J.B., Green, R.C., Naik, V. 1999. Optimal investment, growth options, and security returns. Journal of Finance 54(5): 1553-1607.

Campbell, J., Hilscher, J., Szilagyi, J. 2005. In search of distress risk. Working paper, Harvard University.

Carlson, M., Fisher, A., Giammarino, R. 2004. Price dynamics: Implications for the crosssection of returns. Journal of Finance 59(6): 2577-2603.

Cochrane, J.H. 2005. The risk and return of venture capital. Journal of Financial Economics 75(1): 3-52.

Dichev, I.D. 1998. Is the risk of bankruptcy a systematic risk? Journal of Finance 53(3): 113147.

Fama, E., French, K. 1992. The cross-section of expected stock returns. Journal of Finance 47: $427-465$.

Fama, E., French, K. 1993. Common risk factors in the returns on stocks and bonds. Journal of Financial Economics 43: 3-56.

Fama, E., French, K. 1996. Multifactor explanations of asset pricing anomalies. Journal of Finance 51: 55-84.

Gomes, J., Kogan, L., Zhang, L. 2003. Equilibrium cross-section of returns. Journal of Political Economy 111: 693-732.

Gompers, P.A. 1995. Optimal investment, monitoring, and the staging of venture capital. Journal of Finance 50: 1461-1490.

Gompers, P.A., Lerner, J. 1998. Risk and reward in private equity investments: The challenge of performance assessment. Journal of Private Equity 1(Winter): 5-12.

Gompers, P.A., Lerner, J. 1999. An analysis of compensation in the U.S. venture capital partnership. Journal of Financial Economics 51: 3-44.

Gompers, P.A., Lerner, J. 2000a. The Venture Capital Cycle. Cambridge, MA: MIT Press. 
Gompers, P.A., Lerner, J. 2000b. Money chasing deals? The impact of fund inflows on private equity investments. Journal of Financial Economics 55: 281-325.

Hand, J.R.M. 2005. The value relevance of financial statements in venture capital markets. The Accounting Review 80: 613-648.

Hansen, L.P. 1982. Large sample properties of generalized method of moments estimators. Econometrica 50: 1029-1054.

Heckman, J.J. 1979. Sample selection bias as a specification error. Econometrica 47: 153-161.

Hellman, T.F. 2000. Venture capitalists: The coaches of Silicon Valley. In W.F. Miller, M.G. Hancock and H.S. Rowen, eds., The Silicon Valley Edge: A Habitat for Innovation and Entrepreneurship. Stanford, CA: Stanford University Press.

Hellman, T.F., Puri, M. 2000. The interaction between product market and financing strategy: The role of venture capital. Review of Financial Studies 13: 959-984.

Hellman, T.F., Puri, M. 2002. Venture capital and the professionalization of start-up firms: Empirical evidence. Journal of Finance 57(: 169-198.

Kaplan, S.N., Schoar, A. 2005. Private equity performance: Returns, persistence and capital. Journal of Finance 60(4): 1791-1824.

Keim, D.B. 1983. Size-related anomalies and stock return seasonality: Further empirical evidence. Journal of Financial Economics 12: 13-32.

Lakonishok, J., Shleifer, A., Vishny, R.W. 1994. Contrarian investment, extrapolation, and risk. Journal of Finance 49: 1541-1578.

Lerner, J. 1994. The importance of patent scope: An empirical analysis. Rand Journal of Economics 25: 319-333.

Lerner, J., Merges, R. 1998. The control of technology alliances: An empirical analysis of the biotechnology industry. Journal of Industrial Economics 46: 125-156.

Lerner, J., Schoar, A. 2004. The illiquidity puzzle: Theory and evidence from private equity. Journal of Financial Economics 72: 3-40.

Ljungqvist, A., Richardson, M. 2003. The cash flow, return and risk characteristics of private equity. Working paper, New York University.

Lo, A., MacKinlay, A.C. 1990. Data snooping biases in tests of financial asset pricing models. Review of Financial Studies 3: 431-468. 
Newey, W.K., West, K.D. 1987. A simple, positive semi-definite, heteroskedasticity and autocorrelation consistent covariance matrix. Econometrica 55: 703-708.

Nicholson, S., Danzon, P.M., McCullough, J. 2005. Biotech-pharmaceutical alliances as a signal of asset and firm quality. Journal of Business 78(4): forthcoming.

Rosenberg, B., Reid, K.., Lanstein, R. 1985. Persuasive evidence of market inefficiency. Journal of Portfolio Management 11(3): 9-16.

Sarin, A., Das, S.R., Jagannathan, M. 2003. The private equity discount: An empirical examination of the exit of venture backed companies. Journal of Investment Management 1: $152-177$.

Seppä, T.J. 2003. Essays on the valuation and syndication of venture capital investments. Ph.D. dissertation, Helsinki University of Technology.

Woodward, S.E. 2004. Measuring risk and performance for private equity. Working paper, Sand Hill Econometrics.

Zhang, L. 2004. The value premium. Journal of Finance 60: 67-103.

Zucker, L.G., Darby, M.R., Brewer, M.B. 1998. Intellectual human capital and the birth of U.S. biotechnology enterprises. American Economic Review 88 (1): 290-306. 
Table 1

Descriptive statistics on sample of U.S. biotech companies, 1992-2001

The venture capital market sample is the subset of U.S. firms in Recombinant Capital's (Recap) pre-IPO biotech valuation database that met two criteria: the firm's IPO filing document was at www.sec.gov; and the pre-money valuation date was less than 12 months after a pre-IPO-filing fiscal year-end and was the first financing event after that fiscal year-end. The valuation date is the date the terms of the financing round were agreed on by the firm and the venture investors. The at-IPO sample is the set of Recap firms that had an IPO filing document online (whether they successfully completed the IPO or not).

\begin{tabular}{|c|c|c|c|c|c|c|c|c|c|c|}
\hline \multirow[b]{2}{*}{ Sample } & \multicolumn{7}{|c|}{ Panel A: Distribution of valuation dates } & \multirow[b]{2}{*}{1999} & \multirow[b]{2}{*}{2000} & \multirow[b]{2}{*}{2001} \\
\hline & 1992 & 1993 & 1994 & 1995 & 1996 & 1997 & 1998 & & & \\
\hline Venture market & 15 & 29 & 46 & 60 & 77 & 70 & 67 & 60 & 52 & 5 \\
\hline At-IPO & 0 & 0 & 0 & 1 & 30 & 18 & 11 & 6 & 33 & 4 \\
\hline
\end{tabular}

Panel B: Number of years between the firm's founding and its IPO filing

\begin{tabular}{lccc} 
\# years & \# firms & \# years & \# firms \\
\hline 0 to 1 year & 0 & 7 to 8 years & 14 \\
1 to 2 years & 4 & 8 to 9 years & 14 \\
2 to 3 years & 12 & 9 to 10 years & 6 \\
3 to 4 years & 23 & 10 to 11 years & 5 \\
4 to 5 years & 41 & 11 to 12 years & 6 \\
5 to 6 years & 42 & 12 to 13 years & 2 \\
6 to 7 years & 22 & 13 to 15 years & 2 \\
\hline
\end{tabular}

\begin{tabular}{clcr} 
& \multicolumn{2}{c}{ Panel C: Distribution of firms' 4-digit SICs } & \\
4-digit SIC & \multicolumn{1}{c}{ SIC industry description } & \# firms & \% firms \\
\hline 2834 & Pharmaceutical preparations & 61 & $32 \%$ \\
8731 & Commercial, physical and biological research & 49 & $25 \%$ \\
2836 & Biological products (except diagnostic substances) & 20 & $11 \%$ \\
3845 & Electromedical and electrotherapeutic apparatus & 12 & $6 \%$ \\
2835 & In vitro and in vivo diagnostic substances & 11 & $6 \%$ \\
All others & Various (representing 17 four-digit SICs) & 40 & $20 \%$ \\
\hline
\end{tabular}

Panel D: Firm's headquarter location at the time of its IPO filing

\begin{tabular}{lcc} 
State & \# firms & $\%$ firms \\
\hline California & 90 & $47 \%$ \\
Massachusetts & 27 & $14 \%$ \\
Pennsylvania & 11 & $6 \%$ \\
All others (20 states) & 65 & $33 \%$ \\
\hline
\end{tabular}


Table 2

\section{Medians of key variables at venture capital funding rounds for U.S. biotech companies, 1992-2001}

The pre-IPO sample is the subset of U.S. firms in Recombinant Capital's (Recap) biotech valuation database for which the firm's IPO filing document was at www.sec.gov; and the pre-money valuation date was less than 12 months after a pre-IPO-filing fiscal year-end and was the first financing event after that fiscal year-end. The valuation date is the date the terms of the financing round were agreed on by the firm and the venture investors. The at-IPO sample is the set of Recap firms that had an IPO filing document online.

\begin{tabular}{|c|c|c|c|c|c|c|c|}
\hline & \multicolumn{6}{|c|}{ Venture capital market funding round: } & \multirow{2}{*}{$\begin{array}{l}\text { At the IPO } \\
\text { filing }\end{array}$} \\
\hline & Series A & Series B & Series C & Series D & Series E & Series $\geq F$ & \\
\hline \multicolumn{8}{|l|}{ Valuation data (\$ mil) } \\
\hline Pre-money firm equity value & $\$ 6.3$ & 15 & 27 & 41 & 53 & 55 & 110 \\
\hline Round-to-round raw return (median) & n.app. & $38 \%$ & $58 \%$ & $41 \%$ & $30 \%$ & $2 \%$ & $84 \%$ \\
\hline Round-to-round raw return (mean) & n.app. & $124 \%$ & $92 \%$ & $53 \%$ & $37 \%$ & $24 \%$ & $159 \%$ \\
\hline \multicolumn{8}{|c|}{ Financial statement data (preceding fiscal year; \$ mil) } \\
\hline Cash & $\$ 0.2$ & 1.5 & 2.6 & 3.6 & 5.6 & 9.3 & 12 \\
\hline Noncash assets & $\$ 0.4$ & 0.7 & 1.2 & 1.9 & 2.6 & 2.5 & 3.7 \\
\hline Long-term debt & $\$ \quad 0$ & 0.1 & 0.2 & 0.5 & 0.5 & 0.7 & 0.6 \\
\hline Shareholder equity & $\$-0.2$ & 1.3 & 2.3 & 3.1 & 5.7 & 7.8 & 11 \\
\hline Revenue & $\$ 0.03$ & 0 & 0.05 & 0.2 & 1.2 & 1.9 & 3.6 \\
\hline Selling, general and administration costs & $\$ 0.6$ & 0.8 & 1.3 & 1.7 & 2.1 & 2.4 & 2.9 \\
\hline Research and development expense & $\$ 0.9$ & 1.3 & 2.6 & 4.5 & 5.5 & 6.0 & 6.9 \\
\hline Net income & $\$-1.0$ & -1.8 & -3.5 & -5.4 & -6.7 & -6.9 & -6.7 \\
\hline Money raised at financing round & $\$ 5.6$ & 6.0 & 9.2 & 8.6 & 9.8 & 11 & 40 \\
\hline Stock option dilution $(\%)$ & $6.9 \%$ & $6.6 \%$ & $7.2 \%$ & $11 \%$ & $11 \%$ & $12 \%$ & $11 \%$ \\
\hline Total assets $\div$ pre-money equity value & 0.10 & 0.17 & 0.16 & 0.17 & 0.19 & 0.20 & 0.15 \\
\hline \multicolumn{8}{|l|}{ Non-financial statement information } \\
\hline Firm age at valuation date (yrs.) & 2.6 & 2.5 & 3.2 & 4.0 & 4.8 & 6.9 & 5.9 \\
\hline Prior fiscal year-end to valuation date (yrs.) & 0.18 & 0.34 & 0.34 & 0.34 & 0.26 & 0.34 & 0.46 \\
\hline Equity dilution created at financing date & $46 \%$ & $28 \%$ & $28 \%$ & $19 \%$ & $18 \%$ & $17 \%$ & $26 \%$ \\
\hline Number of patents filed & 0 & 1 & 2 & 3 & 6 & 8 & 6 \\
\hline Scope of patents filed & 0 & 0.67 & 0.50 & 0.67 & 0.60 & 0.47 & 0.50 \\
\hline Number of strategic alliances & 1 & 2 & 2 & 2 & 4 & 4 & 5 \\
\hline Percent of rounds led by corporate investor & $8 \%$ & $12 \%$ & $14 \%$ & $20 \%$ & $24 \%$ & $24 \%$ & $0 \%$ \\
\hline \# observations (except for returns) & 39 & 89 & 105 & 82 & 55 & 34 & 103 \\
\hline
\end{tabular}




\section{Table 3}

\section{Probit model of the determinants of whether a given round of pre-IPO venture financing ultimately led to a venture-backed U.S. biotech company going public (1985-2002)}

$$
\begin{gathered}
\text { IPOIND }_{i k}=\zeta+\sum_{a} \pi_{a} \text { SERIND }_{a i k}+\Omega_{1} \ln \text { RAISED }_{i k}+\Omega_{2} \ln \text { MKTPUB }_{i k}+\Omega_{3} \ln \text { MKTVC }_{i k} \\
+\Omega_{4} \text { CORPIND }_{i k}+\Omega_{5} \text { CALIFIND }_{i k}+\Omega_{6} \text { MASSIND }_{i k}+\varsigma_{i k}
\end{gathered}
$$

The sample is 905 financing rounds in VentureOne's database that were undertaken by U.S. biotechnology companies between 1985 and 2002. IPOIND ${ }_{i k}$, is set to one if, after financing round $k$, firm $i$ went public by $12 / 31 / 02$, and zero otherwise. The mean of IPOIND is 0.47 . Money raised in financing round $k$ is in $\$ 000$ s prior to being log-transformed. All financial statement data are in $\$ 000$ s prior to being log-transformed. The prefix "In" denotes the natural

\begin{tabular}{|c|c|c|c|}
\hline Independent Variables & $\begin{array}{c}\text { Predicted } \\
\text { Coefficient } \\
\text { Sign } \\
\end{array}$ & $\begin{array}{l}\text { Estimated } \\
\text { Coefficient }\end{array}$ & Pr. $>\chi^{2}$ \\
\hline Intercept & & 3.71 & $<0.001$ \\
\hline Indicator: Series A round & & -0.35 & 0.24 \\
\hline Indicator: Series B round & & -0.21 & 0.49 \\
\hline Indicator: Series $\mathrm{C}$ round & & 0.04 & 0.90 \\
\hline Indicator: Series D round & & 0.25 & 0.44 \\
\hline Indicator: Series E round & & 0.27 & 0.43 \\
\hline Indicator: Series $\geq F$ round & & 0.29 & 0.41 \\
\hline $\ln ($ Money raised in financing round $k$ ) & + & 0.28 & $<0.001$ \\
\hline $\ln ($ AMEX public market biotech index) & $?$ & -1.16 & $<0.001$ \\
\hline Indicator: Corporate lead investor & + & 0.21 & 0.24 \\
\hline Indicator: Firm headquartered in California & + & -0.07 & 0.52 \\
\hline Indicator: Firm headquartered in Massachusetts & + & -0.28 & 0.02 \\
\hline $\begin{array}{ll}\text { Log likelihood } & =-485(\mathrm{p} \text {-value }<0.001) \\
\text { OLS adjusted } \mathrm{R}^{2} & =26 \%\end{array}$ & & & \\
\hline
\end{tabular}
$\log$ transformation. 


\section{Table 4}

\section{Log-linear regressions of pre-money equity values at funding rounds on explanatory variables for venture-backed U.S. biotech companies that filed to go public (1992-2001)}

$\ln P R E M V_{i k}=\alpha+\sum_{a} \phi_{a} S E R I N D_{a i k}+\beta \ln M K T_{i k}+\sum_{c} \theta_{c} \ln F S_{c i k}+\sum_{d} \gamma_{d} \ln N F S_{d i k}+\sum_{e} \pi_{e} I N V I N D_{e i k}+v M I L L S_{i k}+\varepsilon_{i k}$

The pre-IPO sample is the subset of U.S. firms in Recombinant Capital's (Recap) biotech valuation database that met two criteria: the firm's IPO filing document was at www.sec.gov; and the pre-money valuation date was less than 12 months after a pre-IPO-filing fiscal year-end and was the first financing event after that fiscal year-end. The valuation date is the date the terms of the financing round were agreed on by the firm and the venture investors. The at-IPO sample is the set of Recap firms that had an IPO filing document online. The prefix "In" denotes the natural log transformation. All financial statement data are in $\$ 000 \mathrm{~s}$ prior to being log-transformed. The dependent variable is $\ln P R E M V_{i k}$, the $\log$ of firm i's pre-money equity value at financing round $k$. GMM asymptotic Z-statistics are in parentheses. In each regression, an intercept and Series indicators are estimated but not reported.

Single, double and triple asterisks denote coefficient estimates that are reliably of the predicted sign at the $5 \%, 2.5 \%$ and $1 \%$ significance levels, respectively, under a one-tailed test.

\begin{tabular}{|c|c|c|c|c|c|}
\hline \multirow[b]{2}{*}{ Independent variables } & \multirow{2}{*}{$\begin{array}{l}\text { Predicted } \\
\text { coef. sign }\end{array}$} & \multicolumn{2}{|c|}{$\begin{array}{l}\text { Pre-IPO + at-IPO } \\
\text { funding rounds }\end{array}$} & \multicolumn{2}{|c|}{$\begin{array}{l}\text { Only pre-IPO } \\
\text { funding rounds }\end{array}$} \\
\hline & & Coef. & Z-stat. & Coef. & Z-stat. \\
\hline \multicolumn{6}{|l|}{ Sector-wide factors $(\mathrm{BIO})$} \\
\hline $\ln ($ AMEX public biotech index $)$ & + & 1.74 & $(15.1)^{* * *}$ & 1.62 & $(13.2)^{* * *}$ \\
\hline \multicolumn{6}{|c|}{ Firm-specific financial statement data $(F S)$} \\
\hline $\ln (1+\mathrm{cash})$ & + & 0.07 & $(3.8)^{* * *}$ & 0.08 & $(3.7)^{* * *}$ \\
\hline $\ln (1+$ noncash assets $)$ & + & 0.12 & $(6.2)^{* * *}$ & 0.13 & $(5.6)^{* * *}$ \\
\hline $\ln (1+$ long-term debt $)$ & - & -0.03 & $(-3.6)^{* * *}$ & -0.03 & $(-3.3)^{* *}$ \\
\hline $\ln (1+$ revenues $)$ & + & -0.00 & $(-0.4)_{* * *}$ & -0.00 & $(-0.1)_{* * *}$ \\
\hline $\ln (1+R \& D$ expense $)$ & + & 0.14 & $(4.6)^{* * *}$ & 0.15 & $(4.3)^{* * *}$ \\
\hline $\ln (1+$ stock option dilution $)$ & - & -1.14 & $(-3.7)^{* * *}$ & -1.44 & $(-4.2)^{* * *}$ \\
\hline Indicator: No stock option data & - & -0.24 & $(-3.8)^{* * *}$ & -0.27 & $(-4.2)^{* * *}$ \\
\hline \multicolumn{6}{|c|}{ Firm-specific non-financial statement data (NFS) } \\
\hline $\ln (1+$ new equity dilution $)$ & - & -1.94 & $(-18.5)^{* * *}$ & -1.88 & $(-17.6)^{* * *}$ \\
\hline $\ln (1+$ number of patents filed $)$ & + & 0.02 & $(1.2)$ & 0.03 & $(1.3)$ \\
\hline $\ln (1+$ scope of patents filed $)$ & + & -0.12 & $(-2.2)$ & -0.15 & $(-2.5)$ \\
\hline $\ln (1+$ number of strategic alliances $)$ & + & 0.07 & $(2.8)^{* * *}$ & 0.08 & $(2.8)^{* * *}$ \\
\hline \multicolumn{6}{|l|}{ Investor-specific attributes (INVIND) } \\
\hline Indicator: Corporate lead investor & + & -0.10 & $(-1.6)$ & -0.09 & $(-1.4)$ \\
\hline \multicolumn{6}{|l|}{ Control for IPO selection bias (MILLS) } \\
\hline Inverse Mills ratio & - & -2.03 & $(-11.5)^{* * *}$ & -1.88 & $(-10.2)^{* * *}$ \\
\hline \# observations [\# firms] & & 584 & [203] & & [193] \\
\hline Series indicators (SERIND) included & & A to If & O rounds & A to & rounds \\
\hline OLS regression adj. $\mathrm{R}^{2}$ & & & $7 \%$ & & $3 \%$ \\
\hline Residual standard deviation & & & .45 & & .47 \\
\hline
\end{tabular}


Table 5

Determinants of the round-to-round returns to venture capital investments for firms that filed to go public (182 U.S. biotech companies, 1992-2001)

$$
\begin{gathered}
\ln \operatorname{EXRET}_{i k}=\delta+\sum_{a} \phi_{a} \Delta S E R I N D_{a i k}+\omega_{1} \ln \operatorname{SIZE}_{i, k-1}+\omega_{2} \ln B T M_{i, k-1}+\beta \Delta \ln E X M K T_{i k}+ \\
\sum_{c} \theta_{c} \Delta \ln F S_{c i k}+\sum_{d} \gamma_{d} \Delta \ln N F S_{d i k}+\sum_{e} \pi_{e} \Delta I N V I N D_{e i k}+\kappa \Delta \ln P R E M S H S_{i k}+v \Delta M I L L S_{i k}+e_{i k}
\end{gathered}
$$

The pre-IPO sample is the subset of U.S. firms in Recap's biotech valuation database that met two criteria: the firm's IPO filing document was at www.sec.gov; and the pre-money valuation date was less than 12 months after a pre-IPO-filing fiscal year-end and was the first financing event after that fiscal year-end. The at-IPO sample is Recap firms that had an IPO filing online. "In" denotes the log transformation. EXRET is one plus the round-to-round excess equity return. Financial statement data are in $\$ 000$ s prior to being log-transformed. $R_{f}$ is one plus the risk-free rate over the return window. GMM asymptotic Z-statistics are in parentheses. Single, double and triple asterisks denote coefficient estimates that are reliably of the predicted sign at the $5 \%, 2.5 \%$ and $1 \%$ significance levels, respectively, under a one-tailed test. In each regression, an intercept and step-up in

\begin{tabular}{|c|c|c|c|c|c|}
\hline \multirow[b]{2}{*}{ Independent variables } & \multirow{2}{*}{$\begin{array}{l}\text { Predicted } \\
\text { coef. sign }\end{array}$} & \multicolumn{2}{|c|}{$\begin{array}{l}\text { Pre-IPO + at-IPO } \\
\text { funding rounds }\end{array}$} & \multicolumn{2}{|c|}{$\begin{array}{l}\text { Only pre-IPO } \\
\text { funding rounds }\end{array}$} \\
\hline & & Coef. & Z-stat. & Coef. & Z-stat. \\
\hline \multicolumn{6}{|l|}{ Risk factors (SIZE, BTM) } \\
\hline$\overline{\ln (\text { Firm size })}$ & - & -0.16 & $(-6.1)^{* * *}$ & -0.12 & $(-4.0)^{* * *}$ \\
\hline $\ln (1+$ firm book-to-market ratio $)$ & + & 0.12 & $(3.6)^{* * *}$ & 0.15 & $(3.8)^{* * *}$ \\
\hline \multicolumn{6}{|l|}{ Sector-wide news $(\triangle E X M K T)$} \\
\hline$\Delta \ln ($ AMEX biotech index $)-\operatorname{Ln}\left(\mathrm{R}_{\mathrm{f}}\right)$ & + & 0.85 & $(7.3)^{* * *}$ & 0.67 & $(4.8)^{* * *}$ \\
\hline \multicolumn{6}{|l|}{ Firm-specific financial statement news $(\Delta F S)$} \\
\hline$\Delta \ln (1+$ cash $)$ & + & 0.09 & $(4.7)^{* * *}$ & 0.09 & $(4.1)^{* * *}$ \\
\hline$\Delta \ln (1+$ noncash assets $)$ & + & 0.06 & $(2.1)^{* *}$ & 0.07 & $(2.5)^{* * *}$ \\
\hline$\Delta \ln (1+$ long-term debt $)$ & - & -0.01 & $(-1.2)$ & -0.01 & $(-1.3)$ \\
\hline$\Delta \ln (1+$ revenues $)$ & + & 0.01 & $(0.8)$ & 0.02 & $(1.7)^{*}$ \\
\hline$\Delta \ln (1+R \& D$ expense $)$ & + & 0.15 & $(3.9)^{* * *}$ & 0.12 & $(3.1)^{* * *}$ \\
\hline$\Delta \ln (1+$ stock option dilution $)$ & - & -0.24 & $(-0.5)$ & 0.21 & $(0.4)$ \\
\hline Indicator: No stock option data & - & 0.05 & $(0.9)$ & -0.03 & $(-0.6)$ \\
\hline \multicolumn{6}{|l|}{ Firm-specific non-financial statement news $(\triangle N F S)$} \\
\hline$\Delta \ln (1+$ new equity dilution $)$ & - & -0.85 & $(-7.6)^{* * *}$ & -0.81 & $(-5.0)^{* * *}$ \\
\hline$\Delta \ln (1+$ number of patents filed $)$ & + & -0.04 & $(-0.9)$ & -0.04 & $(-1.0)$ \\
\hline$\Delta \ln (1+$ scope of patents filed $)$ & + & -0.03 & $(-0.6)$ & -0.00 & $(-0.0)$ \\
\hline$\Delta \ln (1+$ number of strategic alliances $)$ & + & -0.03 & $(-0.6)$ & -0.06 & $(-0.7)$ \\
\hline \multicolumn{6}{|l|}{ Investor-specific attributes news ( $\triangle I N V I N D)$} \\
\hline Indicator: Corporate lead investor, round $k$ & + & 0.14 & $(1.9)^{*}$ & 0.13 & $(1.7)^{*}$ \\
\hline Indicator: Corporate lead investor, round $k-1$ & - & -0.08 & $(-1.4)$ & -0.15 & $(-2.8)^{* * *}$ \\
\hline Indicator: Same lead investor, rounds $k$ and $k-1$ & + & -0.09 & $(-1.9)$ & -0.12 & $(-2.3)$ \\
\hline \multicolumn{6}{|l|}{ Controls ( $\triangle P R E M S H S, \triangle M I L L S)$} \\
\hline$\Delta \ln ($ Pre-money shares outstanding) & - & -0.84 & $(-6.5)^{* * *}$ & -0.82 & $(-4.9)^{* * *}$ \\
\hline$\Delta$ Inverse Mills ratio & - & -0.65 & $(-4.7)^{* * *}$ & -0.62 & $(-3.6)^{* * *}$ \\
\hline \# observations [\# firms] & & \multicolumn{2}{|c|}{$381[182]$} & \multicolumn{2}{|c|}{$288[154]$} \\
\hline Step-up in Series indicators ( $\triangle S E R I N D)$ included & & \multirow{2}{*}{\multicolumn{2}{|c|}{ B to IPO rounds }} & \multicolumn{2}{|c|}{$\mathrm{B}$ to $\mathrm{F}$ rounds } \\
\hline OLS regression adj. $\mathrm{R}^{2}$ & & & & \multicolumn{2}{|c|}{$40 \%$} \\
\hline Residual standard deviation & & \multicolumn{2}{|c|}{0.41} & \multicolumn{2}{|c|}{0.39} \\
\hline
\end{tabular}
Series indicators are estimated but not reported. 


\section{Table 6}

Comparison of the pricing determinants of the visible round-to-round returns to venture capital investments for U.S. biotech companies in the Sand Hill Econometrics database, without conditioning on the ultimate status of the firm (1992-2001)

$\ln R E T_{i k}=\delta+\omega_{1} \ln S I Z E_{i, k-1}+\beta_{1} \Delta \ln A M E X B I O M K T_{i k}+\gamma_{1} \Delta \ln (1+N E W E Q D I L)_{i k}+v \Delta M I L L S_{i k}+e_{i k}$

The sample consists of all companies in the Healthcare sector of Sand Hill Econometrics' financing and valuation database, regardless of the ultimate status of the firm (i.e., firm went public, was acquired, went out of business, or is still a private and in business). Visible roundto-round returns $(R E T)$ are defined as returns for which both the beginning of round and end of round company valuations are present in the Sand Hill database; that is, Sand Hill must have a non-missing post-money valuation for round $k-1$ and a non-missing pre-money valuation for round $k$. The return at an out of business round is set at $-90 \%$. Firm size is the firm's pre-money value at round $k-1$. New equity dilution is the equity dilution created by round $k$ 's equity investment, defined as the money the firm raised in round $k$ divided by the firm's pre-money value at round $k$. New equity dilution is set to zero for acquisition and out of business rounds. The prefix "In" denotes the natural log transformation. GMM asymptotic Z-statistics are in parentheses. A triple asterisk denotes that the coefficient estimate has the predicted sign at the $1 \%$ level under a one-tailed test. A regression intercept is estimated but not reported.

Panel A: Distribution of round-to-round returns in the Sand Hill health sector database Ultimate status of firm Fraction of sample

\begin{tabular}{lr}
\hline Went public & $44.7 \%$ \\
Acquired & $13.9 \%$ \\
Went out of business & $5.7 \%$ \\
Still private \& in business & $35.7 \%$ \\
\hline
\end{tabular}

Panel B: Regression results

\begin{tabular}{|c|c|c|c|}
\hline \multirow[b]{3}{*}{ Hypothesized determinants } & \multirow[b]{3}{*}{$\begin{array}{l}\text { Predicted } \\
\text { coef. sign }\end{array}$} & \multicolumn{2}{|c|}{ Database used in regression: } \\
\hline & & Sand Hill & Table 5, all rounds \\
\hline & & $\begin{array}{c}\text { Coef. } \\
\text { (t-stat.) }\end{array}$ & $\begin{array}{c}\text { Coef. } \\
\text { (t-stat.) }\end{array}$ \\
\hline $\ln ($ Firm size $)$ & - & $\begin{array}{l}-0.07 \\
(-5.6)^{* * *}\end{array}$ & $\begin{array}{l}-0.07 \\
(-3.1)^{* * *}\end{array}$ \\
\hline$\Delta \ln ($ AMEX biotech index $)$ & + & $\begin{array}{l}0.38 \\
(2.8)^{* * *}\end{array}$ & $\begin{array}{l}0.55 \\
(8.4)^{* * *}\end{array}$ \\
\hline$\Delta \ln (1+$ new equity dilution $)$ & - & $\begin{array}{l}-0.15 \\
(-2.6)^{* * *}\end{array}$ & $\begin{array}{l}-0.42 \\
(-3.5)^{* * *}\end{array}$ \\
\hline$\Delta$ Inverse Mills ratio & - & & $\begin{array}{l}-0.51 \\
(-4.1)^{* * *}\end{array}$ \\
\hline \# observations [\# firms] & & $1,669[800]$ & $381[182]$ \\
\hline Adj. $R^{2}$ & & $5 \%$ & $25 \%$ \\
\hline Residual standard deviation & & 0.85 & 0.49 \\
\hline
\end{tabular}

